\title{
Klasifikasi Sel Nukleus Pap Smear Menggunakan Metode Backpropagation Neural Network
}

\author{
Ni Putu Ayu Oka Wiastini, I Ketut Gede Darma Putra, Kadek Suar Wibawa \\ Program Studi Teknologi Informasi, Fakultas Teknik, Universitas Udayana Bukit Jimbaran, Bali, \\ Indonesia Telp. (0361) 701806 \\ Email: ayuwiast@gmail.com, ikgdarmaputra@unud.ac.id, suar wibawa@unud.ac.id
}

\begin{abstract}
Abstrak
Kanker serviks merupakan salah satu penyakit berbahaya yang biasanya menyerang wanita. Kanker serviks dapat dicegah dengan melakukan deteksi dini, yaitu melalui tes pap smear untuk mengenali sel nukleus abnormal. Penyakit serviks secara teratur terbentuk dari perubahan prakanker lebih dari 10 hingga 20 tahun. Penelitian ini mengusulkan pembuatan aplikasi klasifikasi sel nukleus pap smear untuk mempermudah deteksi dini kanker serviks dengan menggabungkan teknik machine learning dan pengolahan citra digital. Aplikasi berfungsi mempermudah para patologi untuk mendeteksi sel nukleus pap smear normal dan abnormal. Tahap yang dilalui untuk memperoleh hasil klasifikasi, yaitu preprocessing, segmentasi, ekstraksi ciri dan klasifikasi. Dua jenis kelas diklasifikasikan pada penelitian ini, yaitu Sel Abnormal dan Sel Normal. Akurasi yang dihasilkan dari proses uji coba, yaitu sebesar $88.8 \%$ dan error rate sebesar $11.2 \%$.
\end{abstract}

Kata Kunci : Neural Network, K-Means Clustering, Regionprops, GLCM, Pap Smear

\begin{abstract}
Cervical cancer is a dangerous disease that usually attacks women. Cervical cancer can be prevented by performing early detection, which is a pap smear test. Cervical disease is regularly formed from changes in precancerous more than 10 to 20 years. This research proposes making an application of pap smear cell classification to facilitate early detection of cervical cancer by combining machine learning techniques and digital image processing. The goal of application is to make it easier for pathologists to detect sel nukleus pap smear normal dan abnormal pap smear nucleus cells. The stage that is passed, namely preprocessing, segmentation, feature extraction and classification. Two types of classes will be classified in this study, which is Abnormal Cell and Normal Cell. The accuracy that generated from the testing process is about $88.8 \%$ and $11.2 \%$ of error rate.
\end{abstract}

Keywords: Neural Network, K-Means Clustering, Regionprops, GLCM, Pap Smear

\section{Pendahuluan}

Kanker merupakan penyakit yang berbahaya dan penyebab kematian tertinggi di Indonesia bahkan dunia. Penyakit kanker leher rahim atau kanker serviks merupakan kanker yang diderita kaum wanita, kanker ini disebabkan oleh Human Papilloma Virus (HPV) [1]. Salah satu penyebab tingginya angka kejadian kanker serviks adalah karena tidak adanya program pendeteksian dini yang efektif bagi wanita dengan sosial ekonomi rendah. Kendala lain adalah kurangnya kesadaran akan penyakit dan akses ke layanan kesehatan. Kanker serviks dapat dicegah jika terdeteksi dan diobati sejak dini, salah satunya adalah dengan melakukan tes pap smear. Tes pap smear dikenal sebagai salah satu metode yang efektif bagi wanita untuk mendeteksi kejadian kanker serviks [2]. Hasil pemeriksaan menunjukkan kondisi sel serviks normal atau abnormal. Pemeriksaan tersebut terdiri atas pengumpulan sampel sel dari daerah tertentu pada serviks, selanjutnya sampel sel tersebut akan diamati dengan bantuan mikroskop dan didiagnosis oleh ahli patologi secara manual [3]. Sistem skrining dengan bantuan komputer bermanfaat untuk mencegah terjadinya kesalahan pada saat analisis hasil pemeriksaan secara manual. Langkah pertama dan yang paling penting dari sistem identifikasi pap smear adalah segmentasi sel yang akurat bersama dengan inti dan sitoplasma.

Masyarakat modern mulai serius memikirkan masalah kesehatan, karena di dalam tubuh yang sehat terdapat jiwa yang sehat [4]. Teknologi identifikasi telah banyak 
dikembangkan saat ini [5], yang dapat mendukung kebutuhan manusia akan informasi. Beberapa penelitian sebelumnya yang telah mencoba untuk meneliti klasifikasi citra pap smear, yaitu dilakukan oleh Ayubu Hassan Mbaga dan Pei ZhiJun dengan judul penelitian Pap Smear Images Classification for Early Detection of Cervical Cancer [6], dimana citra pap smear diklasifikasikan menggunakan metode SVM (Support Vector Machine) dengan rata-rata akurasi sistem, yaitu sebesar 92.961\%. Penelitian lainnya, dilakukan oleh Kangkana Bora, Manish Chowdhury, Lipi B. Mahanta, Malay K. Kundu dan Anup K. Das yang berjudul Pap Smear Image Classification Using Convolutional Neural Network [7], dimana penelitian ini melakukan klasifikasi citra pap smear menggunakan Convolutional Neural Network. Kinerja dua buah metode klasifikasi, yaitu Least Square Support Vector Machine (LSSVM) dan Softmax Regression dipantau pada saat pengujian citra pap smear menggunakan 1.611 citra. Penelitian ini mengungkapkan bahwa salah satu kelemahan Deep Learning adalah waktu pelatihannya tinggi dibandingkan dengan teknik konvensional karena dimensi set fitur yang besar. Teknik feature selection diusulkan pada penelitian ini untuk menyeksi fitur yang mengandung informasi berlebihan. Akurasi pengujian dari penerapan teknik feature selection berkisar antara $90 \%$ sampai dengan $95 \%$.

Penelitian ini mengusulkan pembuatan aplikasi untuk mendeteksi secara dini kanker serviks berdasarkan sel nukleus pap smear menggunakan teknik pengolahan citra digital serta metode machine learning yang berbeda dengan penelitian terdahulu. Tahap pengolahan citra yang dilakukan, yaitu berupa preprocessing dan segmentasi menggunakan metode K-Means Clustering serta Morphological Operation. Ekstraksi ciri yang diusulkan menggunakan dua buah analisis ciri, yaitu tekstur dengan Gray Level Co-Occurrence Matrix dan bentuk dengan Regionprops, kemudian ciri yang telah diekstrak dapat digunakan untuk tahap klasifikasi menggunakan Backpropagation Neural Network (BPNN). Aplikasi diharapkan dapat mempermudah patologi dalam mendeteksi kanker serviks melalui klasifikasi sel pap smear.

\section{Metodologi Penelitian}

Pembuatan deteksi kanker serviks melalui klasifikasi sel nukleus pap smear dilakukan dengan menggabungkan teknik pengolahan citra digital (digital image processing) dan machine learning. Gambaran umum dari sistem klasifikasi sel nukleus pap smear dibagi menjadi lima modul. Modul yang diusulkan adalah Pengumpulan Data, Preprocessing, Segmentasi dan Postprocessing, Ekstraksi Ciri serta Klasifikasi.

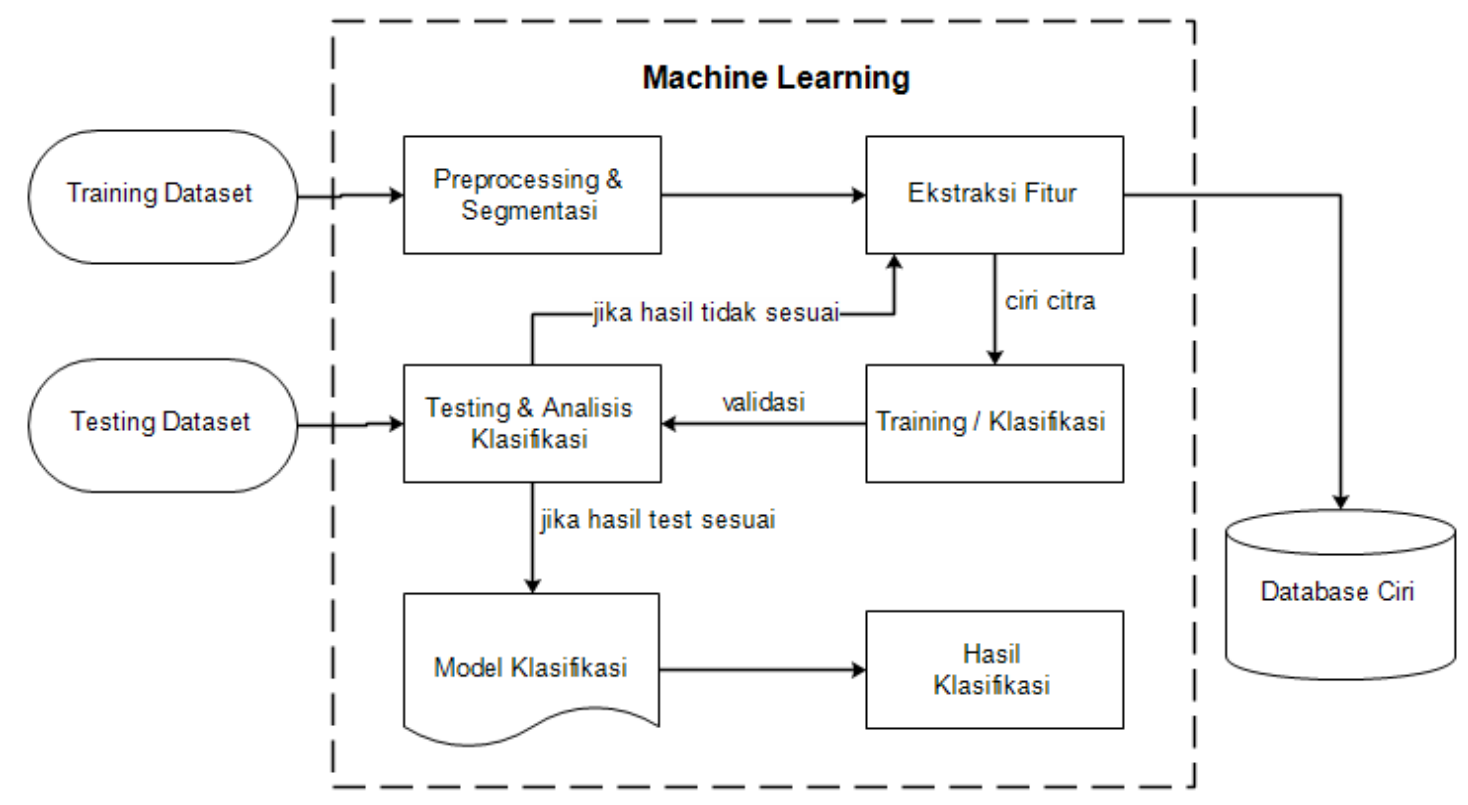

Gambar 1. Arsitektur sistem yang diusulkan

Gambar 1 menunjukkan proses pelatihan serta proses pengujian menggunakan metode yang diusulkan pada penelitian ini. Dataset yang telah didapatkan dibagi menjadi dua, yaitu 
data latih dan data uji. Penelitian ini dibagi menjadi beberapa modul, yaitu modul preprocessing, segmentasi dan post-processing, modul ekstraksi ciri serta modul klasifikasi.

\subsection{Tahap Pengumpulan Data}

Citra input yang digunakan berupa citra sel nukleus pap smear sebanyak 28 citra yang terbagi atas 2 kelas, yaitu Sel Abnormal dan Sel Normal. Citra sel nukleus pap smear diambil dari website DTU Orbit dengan nama dataset Herlev yang terdiri dari citra pap smear dalam bentuk tunggal yang diakuisisi dan diidentifikasi secara manual oleh ahli patologi terampil menggunakan mikroskop yang terkoneksi dengan sebuah frame grabber [8].

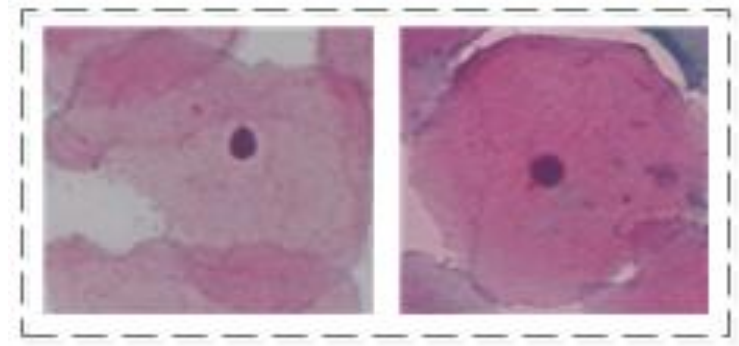

(a)

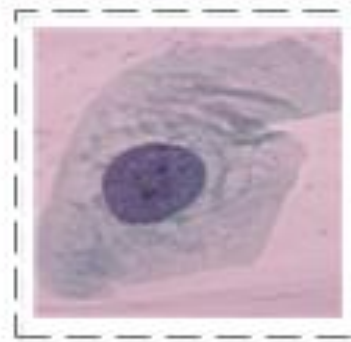

(b)

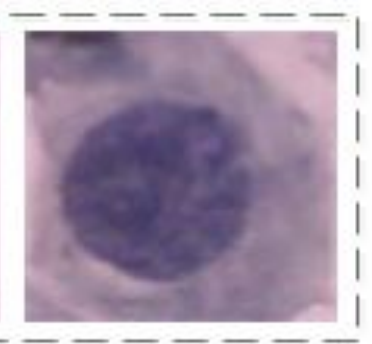

Gambar 2. Citra Sel Nukleus Pap Smear, (a) Sel Normal, (b) Sel Abnormal

\subsection{Tahap Preprocessing}

Tahap preprocessing bertujuan untuk memperbaiki kontras dan kualitas dari citra input, dimana citra papsmear memiliki kontras yang sangat rendah. Perbaikan citra adalah proses meningkatkan kualitas visual suatu citra, sehingga hasilnya lebih sesuai dari pada citra aslinya [9]. Penelitian ini mengusulkan metode Histogram Equalization untuk meningkatkan kontras citra dan Gaussian Filter menghilangkan noise/derau.

\subsection{Tahap Segmentasi}

Segmentasi digunakan untuk memisahkan foreground dengan background citra, sedangkan post-processing digunakan untuk menyempurnakan hasil segmentasi. Metode segmentasi yang diusulkan adalah metode K-Means Clustering dan dilanjutkan dengan tahap post-processing dengan melakukan operasi morfologi pada citra biner.

\subsection{Tahap Ekstraksi Ciri}

Ekstraksi ciri merupakan tahap mengekstrak ciri dari citra hasil segmentasi menggunakan ciri tekstur dengan Gray Level Co-Occurrence Matrix (GLCM) dan bentuk dengan Regionprops. Ekstraksi ciri merupakan tahap yang paling penting untuk tahap klasifikasi, karena citra dapat dibedakan diantara kelas satu dengan kelas lainnya berdasarkan cirinya. Ciri yang telah diekstrak, kemudian disimpan di dalam database ciri yang selanjutnya digunakan dalam tahap identifikasi.

\subsection{Tahap Klasifikasi}

Tahap klasifikasi dibagi menjadi dua proses, yaitu proses pelatihan dan proses pengujian. Proses pelatihan merupakan tahap pembelajaran data latih dari citra pap smear menggunakan metode Backpropagation Neural Network, sehingga diperoleh model yang digunakan untuk meguji data uji baru yang telah disiapkan. Pengujian data uji dilakukan dengan memanggil model klasifikasi tersebut, sehingga tidak perlu melakukan tahap training kembali.

\section{Kajian Pustaka}

Kajian pustaka memuat materi yang menjadi referensi penelitian ini. Referensi yang dimuat, yaitu terkait metode yang digunakan untuk pengolahan citra digital dan machine learning. Metode yang dibahas adalah K-Means Clustering, Gray Level Co-Occurrence Matrix (GLCM), Regionprops, dan Backpropagation Neural Network.

\subsection{Machine Learning}


Machine Learning atau pembelajaran mesin merupakan salah satu pendekatan yang ada pada Artificial Intelegence (Al), dimana digunakan untuk meniru perilaku manusia agar dapat menyelesaikan masalah [10]. Machine Learning mencoba untuk menirukan bagaimana proses manusia belajar dan mengambil keputusan. Metode Machine Learning (ML) lebih mudah untuk diimplementasikan dan berkinerja lebih baik daripada pendekatan statistik klasik [11].

\subsection{Pap Smear}

Sel nukleus pap smear biasanya dapat dilihat melalui mikroskop oleh ahli patologi atau ahli dibidang pap smear. Para ahli patologi mengungkapkan bahwa, metode pap smear merupakan sebuah metode yang digunakan untuk mendeteksi secara dini keberadaan virus HPV [12]. Tes pap smear adalah metode pendeteksian dini pada kanker serviks dengan mengambil sel serviks pada dinding rahim dan kemudian diperiksa dibawah mikroskop. Sel normal memiliki luas inti yang lebih kecil, sedangkan sel yang abnormal terjadi peningkatan luas nukleus.

\subsection{K-Means Clustering}

Segmentasi merupakan proses membagi citra ke dalam beberapa beberapa daerah atau objek yang memiliki kemiripan atribut (homogen) [13]. Segmentasi bertujuan untuk mengambil objek citra yang bermakna dan memisahkan dari objek yang tidak dikehendaki. Clustering merupakan proses pengelompokan sejumlah besar data menjadi beberapa kelas berdasarkan karakteristik masing-masing data [14]. K-means Clustering merupakan metode unsupervised learning yang digunakan untuk mengelompokkan suatu data menjadi beberapa kelompok (cluster) [15]. Algoritma yang digunakan pada metode K-Means Clustering adalah sebagai berikut [16] :

1. Menentukan jumlah cluster pada data, kemudian hitung nilai centroid secara acak.

2. Hitung jarak dari pixel ke centroid, serta lakukan pengelompokkan pixel berdasarkan jarak yang paling dekat.

3. Hitung kembali centroid melalui perhitungan rata-rata pixel tiap cluster dan jadikan sebagai centroid baru, kemudian pixel dikelompokkan kembali sesuai dengan centroid tersebut.

4. Perhitungan centroid baru dilakukan jika masih terdapat pixel yang berpindah cluster, namun apabila tidak ada nilai pixel yang berpindah cluster, maka proses clustering akan diakhiri.

\subsection{Ekstraksi Ciri}

Ekstraksi ciri merupakan langkah penting dalam proses klasifikasi, dimana tujuannya untuk mengekstraksi informasi yang relevan pada sebuah objek yang selanjutnya menjadi ciri pada setiap kelas [17]. Setiap gambar memiliki informasi fitur low-level yang unik [18]. Contoh fitur low-level adalah warna, tekstur, bentuk, dan sebagainya.

\subsubsection{Regionprops}

Region Properties (regionprops) adalah fungsi dalam image processing toolbox yang telah tersedia pada Matlab yang memungkinkan pengguna untuk mengukur/mengekstrak sekumpulan properti untuk sebuah gambar. Citra kemudian diberikan label menggunakan nilai yang diperoleh dari wilayah yang telah diukur sebelumnya. Fitur-fitur yang dapat diesktrak adalah Area, Centroid, Orientation, Major Axis Length, Extrema, Minor Axis Length, Eccentricity dan Diameter [19].

\subsubsection{Gray Level Co-Occurence Matrix (GLCM)}

Gray Level Co-Occurence Matrix (GLCM) merupakan metode analisis tekstur/ekstraksi ciri yang mempunyai sekumpulan informasi mengenai derajat keabuan (intensitas) suatu piksel dengan tetangganya pada jarak dan orientasi yang tepat. Metode GLCM umumnya menggunakan empat arah horizontal, vertical dan dua arah diagonal [20]. Fitur tekstur yang dapat diekstrak dari metode GLCM adalah Contrast, Energy, Entropy dan Homogeneity. Fitur yang digunakan pada penelitian ini adalah contrast dan homogeneity. Ciri contrast dan homogeneity dapat dihitung menggunakan Persamaan 1 dan 2 [21]. 


$$
\begin{aligned}
& \text { Contrast }=\sum i \sum j(i-j)^{2} P(i, j) \\
& \text { Homogeneity }=\sum i \sum j \frac{P(i, j)}{1+\left(i-j^{2}\right.}
\end{aligned}
$$

Variabel $P(i, j)$ menunjukkan matriks dari metode GLCM, dimana j menunjukkan nilai piksel ke-j, sedangkan i merupakan ruang warna ke-i . Fitur kontras (contrast) digunakan untuk menghitung tingkat keabuan pada suatu citra. Semakin besar perbedaan tingkat keabuan, maka akan semakin tinggi kontrasnya. Sebaliknya, semakin sedikit perbedaan tingkat keabuan antara dua piksel, maka semakin rendah kontrasnya. Fitur homogenitas (homogeneity) menghitung tingkat homogenitas dari warna abu-abu pada suatu citra. Nilai homogenitas akan lebih tinggi pada citra dengan tingkat keabuan yang homogen.

\subsection{Backpropagation Neural Network (BPNN)}

Algoritma Backpropagation adalah metode yang paling umum digunakan dalam pelatihan jaringan saraf tiruan [22]. Jaringan Backpropagation merupakan bagian dari jaringan Multilayer Perceptron, tetapi dengan algoritma pembelajaran yang berbeda. Pemrosesan jaringan syaraf tiruan dilakukan dalam tiga fase, yaitu pelatihan, validasi, dan pengujian. Model dari jaringan Backpropagation terdiri atas, input layer, hidden layer dan output layer. Hasil klasifikasi semakin akurat, jika lebih banyak dataset input yang digunakan untuk pelatihan. Jaringan Backpropagation dapat lebih banyak melakukan proses pembelajaran dengan menggunakan data latih yang lebih banyak.

\section{Hasil dan Pembahasan}

Bagian hasil dan pembahasan membahas mengenai proses pengujian yang dilakukan pada GUI (Graphical User Interface) disertai dengan analisa dari proses pengujian. Pengujian dilakukan pada proses load citra uji, tahap preprocessing, segmentasi dan postprocessing, ekstraksi ciri serta pelatihan dan pengujian citra. Analisa dilakukan terhadap hasil pengujian yang diperoleh.

\subsection{Proses Pengujian}

Proses pengujian pada penelitian ini menggunakan sebanyak 9 citra uji, sedangkan untuk proses pelatihan menggunakan sebanyak 19 citra. Model Backpropagation diimplementasikan pada proses pengujian untuk menentukan kelas dari masing-masing data uji. Proses pengujian yang dibahas meliputi, pengolahan citra digital, ekstraksi ciri dan klasifikasi.
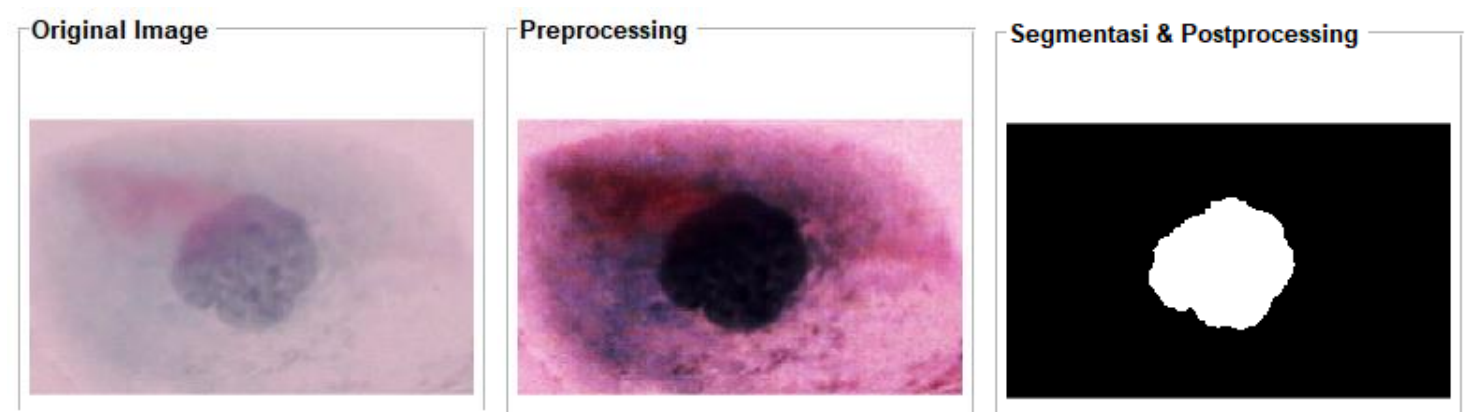

Gambar 3. Proses Pengolahan Citra Digital

Proses pengolahan citra digital pada penelitian meliputi, preprocessing dan segmentasi. Gambar 3 menunjukkan 'Original Image' yang berupa citra asli, 'Preprocessing' yang merupakan hasil proses preprocessing, 'Segmentasi \& Postprocessing' yang berupa citra hasil segmentasi dan juga hasil dari proses postprocessing yang berupa citra biner. Citra biner hasil tahap postprocessing diekstrak cirinya menggunakan ekstraksi ciri tekstur dengan Gray Level Co-Occurrence Matrix (GLCM) dan bentuk dengan regionprops. 


\begin{tabular}{|c|c|c|}
\hline & Ciri & Nilai \\
\hline 1 & Area & 7144 \\
\hline 2 & Perimeter & 324.614 \\
\hline 3 & Contrast & 0.071138 \\
\hline 4 & Homogeneity & 0.99183 \\
\hline
\end{tabular}

Gambar 4. Proses Ekstraksi Ciri

Penelitian ini menggunakan dua buah analisis ciri, yaitu analisis tekstur dengan Gray Level Co-Occurence Matrix (GLCM) dan analisis bentuk dengan Regionprops. Metode ekstraksi ciri tekstur menggunakan GLCM mengekstrak ciri contrast dan homogeneity, sedangkan metode ekstraksi ciri regionprops mengekstrak ciri bentuk area dan perimeter pada setiap citra uji. Total ciri yang dapat diekstrak dari satu buah citra adalah sebanyak empat buah ciri, dimana ditampilkan pada Gambar 4. Ciri yang paling terlihat berbeda antara sel nukleus pap smear normal dan abnormal adalah dari ciri bentuk, karena sel abnormal cenderung memiliki inti sel yang berukuran lebih besar dan sel normal memiliki ukuran sel yang lebih kecil.

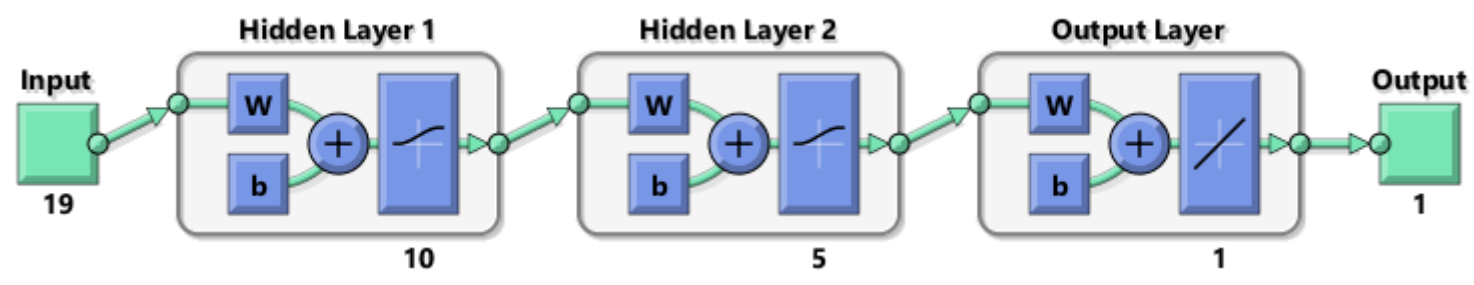

Gambar 5. Model Backpropagation Neural Network

Arsitektur model dari metode klasifikasi Backpropagation Neural Network yang digunakan digambarkan pada Gambar 5. Model dari Backpropagation ditentukan pada saat training dataset, dimana model yang ditentukan berpengaruh terhadap akurasi pengenalan yang dihasilkan. Arsitektur yang dibangun, yaitu berupa Input, dua buah hidden layer, output layer dan hasil keluaran. Hidden layer pertama memuat sebanyak 10 buah neuron dengan fungsi aktivasi atau fungsi pembelajaran yang digunakan adalah sigmoid biner (logsig), sedangkan hidden layer kedua memuat sebanyak 5 buah neuron dengan fungsi aktivasi sigmoid biner (logsig). Fungsi aktivasi yang digunakan pada bagian output layer adalah fungsi backpropagation Levenberg-Marquardt (trainlm). Data dapat melakukan pembelajaran melalui model hasil training berdasarkan jumlah epoch atau iterasi yang ditentukan.

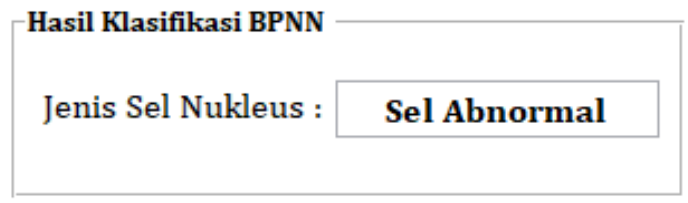

Gambar 6. Hasil Klasifikasi

Gambar 6 menunjukkan tampilan GUI pada saat proses klasifikasi data uji dilakukan. Hasil klasifikasi berdasarkan data uji yang diujikan sebelumnya menggunakan metode Backpropagation Neural Network menunjukkan bahwa data uji dikenali sebagai kelas Sel Abnormal. Aplikasi akan memberikan hasil kelas output berupa 'Sel Abnormal' sebagai prediksi kelas data uji pada GUI, karena memiliki kemiripan ciri yang lebih besar daripada kelas Sel Normal. 


\subsection{Analisa}

Analisa berdasarkan pengujian yang telah dilakukan sebelumnya bertujuan untuk mengetahui akurasi keseluruhan dari kinerja pengenalan citra sel nukleus pap smear menggunakan metode yang diusulkan serta mengetahui pengaruh dari ekstraksi ciri tekstur dan warna untuk proses pengenalan citra pap smear. Hasil pengujian menggunakan citra uji ditampilkan pada Tabel 1 dan Tabel 2.

Tabel 1. Confusion Matrix

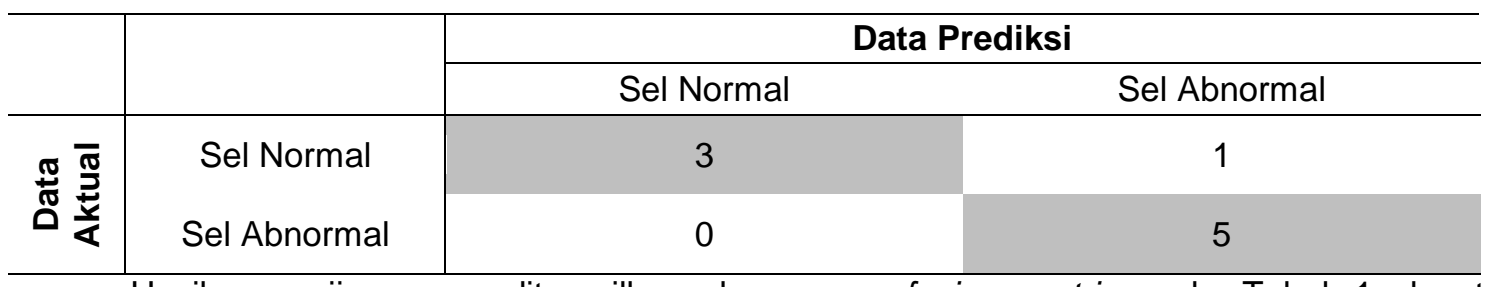

Hasil pengujian yang ditampilkan dengan confusion matrix pada Tabel 1 dapat disimpulkan bahwa, kelas Sel Normal diklasifikasi dengan benar sebanyak 3 citra, sedangkan diklasifikasi sebagai Sel Abnormal sebanyak 1 citra. Kelas Sel Abnormal yang diklasifikasi dengan benar sebanyak 5 citra dan tidak ada citra yang salah terklasifikasikan. Akurasi yang dihasilkan dari hasil pengujian tersebut dengan menggunakan 9 citra uji, yaitu sebesar $88.8 \%$ dan error rate sebesar $11.2 \%$.

Tabel 2. Pengaruh Ekstraksi Ciri

\begin{tabular}{ccc}
\hline \multirow{2}{*}{ Ekstraksi Ciri } & \multicolumn{2}{c}{ Akurasi (\%) } \\
\cline { 2 - 3 } & Pelatihan & Pengujian \\
\hline Ciri Tekstur (GLCM) & 63.1 & 44.4 \\
Ciri Bentuk (Regionprops) & 89.4 & 77.7 \\
Kombinasi Ciri Tekstur dan Bentuk & 100 & 88.8 \\
\hline
\end{tabular}

Tabel 2 menampilkan hasil uji coba pengaruh ekstraksi ciri tekstur menggunakan metode Gray Level Co-Occurrence Matrix (GLCM), ekstraksi ciri bentuk menggunakan Regionprops dan kombinasi kedua metode tersebut. Akurasi pengujian yang dihasilkan pada Tabel 2 menyatakan bahwa analisis ciri bentuk sangat besar pengaruhnya terhadap proses pengenalan citra sel nukleus pap smear, namun kombinasi dari kedua buah analisis ciri tersebut sangat membantu meningkatkan akurasi pengenalan.

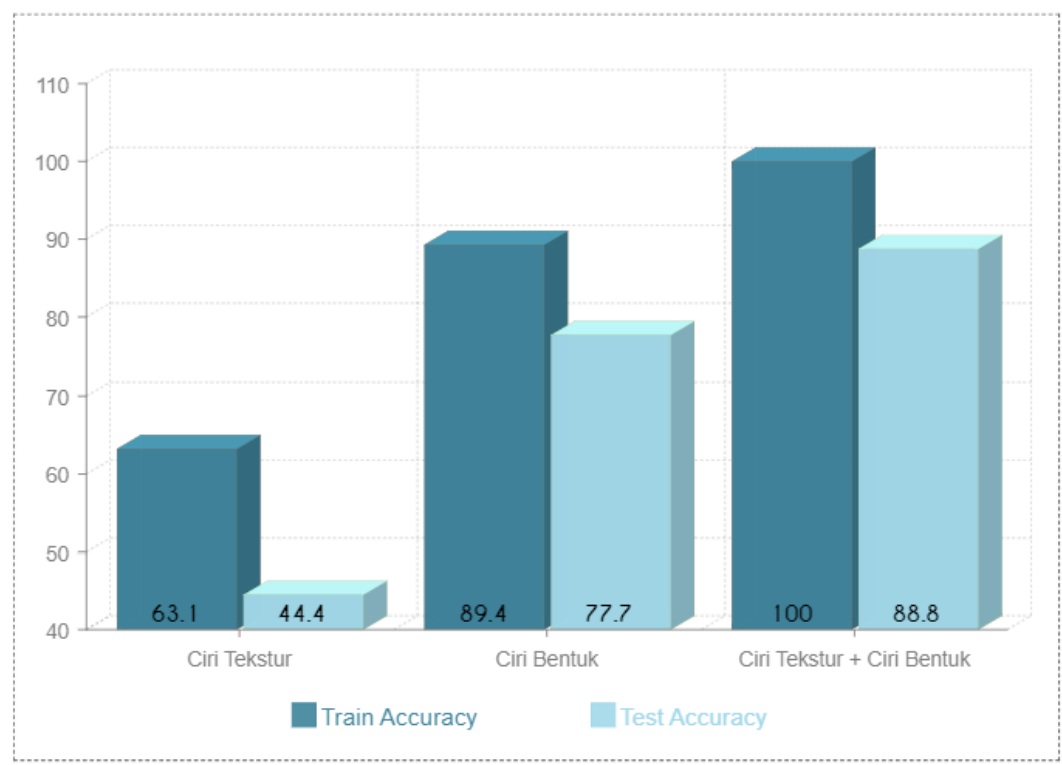

Gambar 6. Grafik Pengaruh Ekstraksi Ciri 
Skenario pengujian ekstraksi ciri yang paling optimal ditunjukkan pada penggunaan kombinasi ekstraksi ciri tekstur Gray Level Co-Occurrence Matrix (GLCM) dan ekstraksi ciri bentuk Regionprops secara bersamaan dengan akurasi pengujian $88.8 \%$. Akurasi pengujian dipengaruhi oleh objek dataset sel nukleus pap smear yang digunakan. Ciri yang dapat dilihat dari objek sel nukleus pap smear yang digunakan pada penelitian ini adalah perbedaan bentuk dan juga teksturnya. Sel nukleus normal cenderung memiliki ukuran sel yang lebih kecil dan tekstur yang halus karena memiliki intensitas warna yang lebih homogen, sedangkan sel nukleus abnormal memiliki ukuran sel yang besar dan tekstur yang cenderung kasar.

\section{Kesimpulan}

Sistem deteksi dini pada kanker serviks berdasarkan analisis sel nukleus pap smear menggunakan teknik berbasis komputer dibutuhkan dalam dunia medis untuk mempermudah pendeteksian secara dini oleh ahli patologi dan menghemat waktu pada saat pengklasifikasian sel nukleus. Penelitian ini menggabungkan teknik machine learning dan pengolahan citra digital untuk mengidentifikasi sel nukleus pap smear normal dan abnormal. Kombinasi fitur tekstur GLCM dan bentuk regionprops berhasil meningkatkan akurasi pengenalan daripada hanya menggunakan salah satu fitur saja. Klasifikasi berbasis Backpropagation Neural Network (BPNN) mendapatkan akurasi pengenalan sebesar $88.8 \%$ dan error rate sebesar $11.2 \%$ dengan menguji 9 citra uji. Kesalahan deteksi dari beberapa data yang diujikan disebabkan oleh hasil segmentasi yang kurang sempurna.

\section{Daftar Pustaka}

[1] Y. Kusumawati, R. W. Nugrahaningtyas, and E. N. Rahmawati, "Pengetahuan, Deteksi Dini dan Vaksinasi HPV sebagai Faktor Pencegah Kanker Serviks di Kabupaten Sukoharjo," KESMAS: Jurnal Kesehatan Masyarakat, vol. 11, no. 2, pp. 204-213, 2016.

[2] H. Ashtarian, E. Mirzabeigi, E. Mahmoodi, and M. Khezeli, "Knowledge About Cervical Cancer and Pap Smear and The Factors Influencing The Pap Test Screening Among Women," International Journal of Community Based Nursing and Midwifery, vol. 5, no. 2, pp. 188-195, 2017.

[3] M. Sholik and C. Fatichah, "Klasifikasi Sel Serviks pada Citra Pap Smear berdasarkan Fitur Bentuk Deskriptor Regional dan Fitur Tekstur Uniform Rotated Local Binary Pattern," Jurnal IImiah Teknologi Informasi, vol. 15, p. 214, Jul. 2017.

[4] N. K. A. Wirdiani and A. Sudana, "Medicinal plant recognition of leaf shape using Localized Arc Pattern Method," International Journal of Engineering and Technology, vol. 8, no. 4, pp. 1847-1854, 2016.

[5] I. K. S. Widiakumara, I. K. G. D. Putra, and K. S. Wibawa, "Aplikasi Identifikasi Wajah Berbasis Android," Lontar Komputer: Jurnal IImiah Teknologi Informasi, vol. 8, no. 3, pp. 200-207, 2017.

[6] A. H. Mbaga and P. ZhiJun, "Pap Smear Images Classification for Early Detection of Cervical Cancer," International Journal of Computer Applications, vol. 118, no. 7, pp. 1016, 2015.

[7] K. Bora, M. Chowdhury, L. B. Mahanta, M. K. Kundu, and A. K. Das, "Pap Smear Image Classification using Convolutional Neural Network," in Proceedings of the Tenth Indian Conference on Computer Vision, Graphics and Image Processing, 2016, p. 55.

[8] J. Jantzen and G. Dounias, "Analysis of Pap-Smear Image Data," in Nature-Inspired Smart Information Systems 2nd Annual Symposium, 2006.

[9] A. A. Riadi, "Analisa Perbaikan Kualitas Kontras Citra X-Ray Menggunakan Metode Exposure Based Sub-Image Histogramequalization (ESIHE)" Jurnal Teknik Mesin, Elektro dan IImu Komputer, vol. 7, no. 1, pp. 305-310, 2016.

[10] A. Ahmad, "Mengenal Artificial Intelligence, Machine Learning, Neural Network, dan Deep Learning," Yayasan Cahaya Islam Jurnal Teknologi Indonesia, 2017.

[11] S. Loussaief and A. Abdelkrim, "Machine Learning Framework for Image Classification," Advances in Science, Technology and Engineering Systems Journal, vol. 3, no. 1, pp. 110, 2018.

[12] T. Hidayatulloh, A. Herliana, and T. Arifin, "Klasifikasi Sel Tunggal Pap Smear Berdasarkan Analisis Fitur Berbasis Naive Bayes Classifier dan Particle Swarm Optimization," Suara Wawasan Sukabumi, vol. 4, no. 2, pp. 186-193, 2016. 
[13] A. S. R. M. Sinaga, "Implementasi Teknik Thresholding pada Segmentasi Citra Digital," Jurnal Mantik Penusa, vol. 1, no. 2, pp. 48-51, 2017.

[14] A. S. Devi, I. K. G. D. Putra, and I. M. Sukarsa, "Implementasi Metode Clustering DBSCAN pada Proses Pengambilan Keputusan," Lontar Komputer: Jurnal IImiah Teknologi Informasi, vol. 6, no. 3, pp. 185-191, 2015.

[15] A. P. AM and M. Murinto, "Segmentasi Citra Batik Berdasarkan Fitur Tekstur Menggunakan Metode Filter Gabor dan K-Means Clustering," Jurnal Informatika, vol. 10, no. 1, pp. 1173-1179, 2016.

[16] F. G. Febrinanto, C. Dewi, and A. T. Wiratno, "Implementasi Algoritme K-Means sebagai Metode Segmentasi Citra dalam Identifikasi Penyakit Daun Jeruk," Jurnal Pengembangan Teknologi Informasi dan IImu Komputer, vol. 2, no. 11, pp. 5375-5383, 2018.

[17] S. Medhi, C. Ahmed, and R. Gayan, "A Study on Feature Extraction Techniques in Image Processing," International Journal of Computer Sciences and Engineering, vol. 4, no. 7, pp. 89-93, 2016.

[18] I. G. A. Triwayuni, I. K. G. D. Putra, and I. P. A. E. Pratama, "Content Based Image Retrieval Using Lacunarity and Color Moments of Skin Diseases," Indonesian Journal of Electrical Engineering and Computer Science, vol. 9, no. 1, pp. 243-248, 2018.

[19] N. J. Shoumy, S. N. Yaakob, P. Ehkan, M. S. Ali, and S. Khatun, "Feature Extraction for Neural Network Pattern Recognition for Bloodstain Analysis," International Journal of Applied Engineering Research, vol. 11, no. 15, pp. 8583-8589, 2016.

[20] N. L. W. S. R. Ginantra, "Deteksi Batik Parang Menggunakan Fitur Co-Occurence Matrix dan Geometric Moment Invariant dengan Klasifikasi KNN," Lontar Komputer: Jurnal IImiah Teknologi Informasi, vol. 7, no. 1, pp. 40-50, 2016.

[21] S. H. S. Al-Kilidar and L. E. George, "Texture Recognition Using Co-Occurrence Matrix Features and Neural Network," Journal of Theoretical and Applied Information Technology, vol. 95, no. 21, pp. 5949-5961, 2017.

[22] K. S. Harsh Kukreja, Bharath N, Siddesh C S, "An Introduction to Artificial Neural Network," International Journal of Advance Research and Innovative Ideas in Education, vol. 1, no. 5, pp. 27-30, Sep. 2016. 